Original article

\title{
Characterization of pregnancy-associated glycoproteins extracted from zebu (Bos indicus) placentas removed at different gestational periods
}

\author{
Noelita Melo SousA ${ }^{\mathrm{a}}$, Benoit RemY ${ }^{\mathrm{b}}$, Bouchra El AMIRI ${ }^{\mathrm{b}}$, \\ José Ricardo De FigueIREdo ${ }^{\mathrm{a}}$, Henri BANGA-MвоKO ${ }^{\mathrm{b}}$, \\ Paulo Bayard DiAs GonÇALVES ${ }^{\mathrm{a}}$, Jean-François BECKERS ${ }^{\mathrm{b} *}$ \\ ${ }^{a}$ Faculty of Veterinary Medicine, Rural Sciences Center, Federal University of Santa Maria, \\ RS 97105-900, Brazil \\ ${ }^{\mathrm{b}}$ Physiology of Reproduction, Faculty of Veterinary Medicine, University of Liege, \\ 4000, Belgium
}

(Received 14 February 2002; accepted 21 May 2002)

\begin{abstract}
In the present work, two biochemical approaches were used to characterize PAGs isolated from Bos indicus fetal cotyledons removed at different gestational ages. The first procedure included acidic and ammonium sulfate precipitations, anion and cation exchange chromatographies and the second included pepstatin-agarose affinity chromatography. A bovine PAG radioimmunoassay was used to monitor the immunoreactivity throughout the isolation procedures. The most immunoreactive fractions issued from cation exchange and affinity chromatographies were analyzed by SDS-PAGE and Western blotting, before transfer to a polyvinylidene difluoride (PVDF) membrane for $\mathrm{NH}_{2}$-microsequence determination. Use SDS-PAGE and Western blotting, different isoforms of PAG with apparent molecular masses of 51 to $69 \mathrm{kDa}$ and isoelectric points varying from 4.4 to 6.7 were identified in the placentas from different gestational ages. $\mathrm{N}$-terminal microsequencing (10 to 25 aa long) indicates the expression of one single terminal amino acid sequence in the Bos indicus placenta, which is $100 \%$ identical to the bovine PAG-1.
\end{abstract}

pregnancy-associated glycoprotein / purification / zebu / placenta / N-terminal microsequencing

\footnotetext{
* Correspondence and reprints

E-mail: jfbeckers@ulg.ac.be
} 


\section{INTRODUCTION}

Recently, a highly polymorphic family of placenta-expressed proteins was discovered in the ruminant species. These pregnancy-associated glycoproteins (PAGs), also known as pregnancy-specific protein $B$ (PSPB) [2] and pregnancy serum protein (PSP-60) [3], constitute a large family of aspartic proteinases, showing the greatest sequence identity with pepsinogens [25]. PAGs are synthesized by mono and/or binucleate trophoblastic cells, some of which are released in the maternal circulation during almost the whole pregnancy period [15, $18,29]$. In veterinary practices, their measurements in the maternal bloodstream are useful for both pregnancy confirmation and follow-up of the trophoblastic function [19].

Two approaches have been used for PAG characterization in the ruminant placentas: biochemistry and molecular biology. Biochemical procedures allow the isolation of different PAG molecules, heterogeneous in molecular weight and charge $[2,6,26]$. Further characterization of these molecules by means of $\mathrm{NH}_{2}$-terminal amino acid sequencing has revealed the existence of one PAG in cows (boPAG 67 ) [28], four in ewes (ovPAG $_{55}$, ovPAG $_{60}$, ovPAG $_{61}$ and ovPAG $\left._{65}\right)$ [26] and three in goats $\left(\mathrm{caPAG}_{55}\right.$, $\mathrm{caPAG}_{59}$ and $\mathrm{caPAG}_{62}$ ) [6]. A larger variety of PAG cDNAs has been identified in bovine (boPAG-1 to -21) [8, 25, 27], ovine (ovPAG-1 to -9) [8, 26, 27] and caprine placental libraries (caPAG-1 to -11) [7] using molecular biology techniques. As described by Green et al. [8], these PAG cDNAs appear to be differentially expressed in early, mid and late gestational periods. However, in spite of several attempts to purify the different PAG molecules identified by nucleotidic sequencing, only two PAGs (boPAG 67 and ovPAG ${ }_{65}$ ) could be successfully shown by both approaches [25, 26, 28].

In this paper we describe for the first time the isolation, characterization and $\mathrm{N}$-terminal microsequencing of PAG molecules extracted from zebu (Bos indicus) placentas removed at different gestational ages. The biochemical protocol previously described for PAG isolation in the ruminant species was used to purify and characterize PAGs extracted from placentas removed late in pregnancy. In placentas removed earlier in pregnancy, pepstatin affinity chromatographies were used for the first time to enrich the preparations in PAG molecules before $\mathrm{N}$-terminal microsequencing of immunoreactive proteins.

\section{MATERIALS AND METHODS}

\subsection{Assays for total protein and PAG-immunoreactivity}

Total protein (TP) concentrations of all the fractions were determined by using the method of Lowry et al. [12] with bovine serum albumin (BSA; ICN Biochemicals Inc., Aurora, $\mathrm{OH}$ ) as the standard. The estimation of PAG concentrations in each purification step was determined by a bovine PAG RIA (boPAG-1 RIA) [29]. Pure boPAG-1 was used as the tracer and standard, and the antibody (R497) against boPAG-1 was used for binding at a final dilution of 1:300 000 .

\subsection{Collection of cotyledons}

Uteri were collected from pregnant zebu (Bos indicus) females within 5-30 min of slaughter. Fetal cotyledons were immediately dissected away from caruncular tissue, washed with $0.9 \% \mathrm{NaCl}$, and stored at $-20{ }^{\circ} \mathrm{C}$ until use. The stage of pregnancy was estimated by measurement of fetal crown-rump length. According to the gestational age, the placentas were classified as early (10-11 weeks), middle (20-21 weeks) or late placentas (30-31 weeks). Figure 1 schematically shows the protocols of fractionation of the proteins extracted from the zebu placentas. 


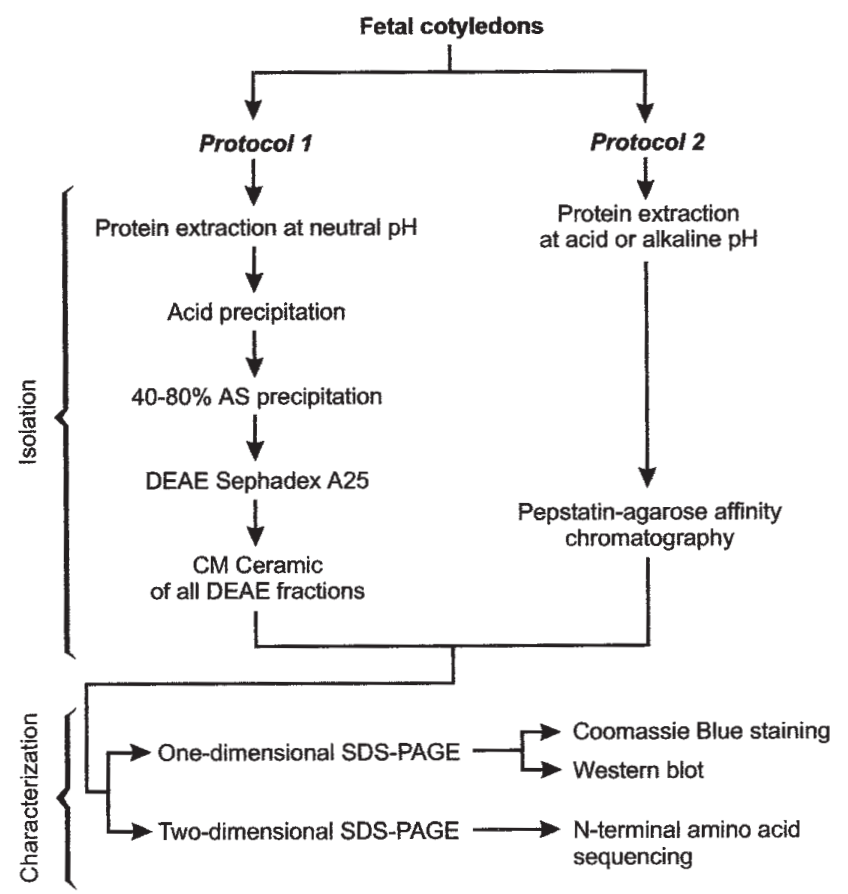

Figure 1. Schematic outline of PAG purification from zebu placentas removed in late (Protocol 1), middle or early (Protocol 2) gestational periods.

\subsection{Protocol 1}

\subsubsection{Protein extraction}

Approximately $1920 \mathrm{~g}$ of fetal cotyledons from late placentas were thawed, finely minced, and homogenized with a hand mixer in $10 \mathrm{mM}$ potassium phosphate buffer $\left(\mathrm{KH}_{2} \mathrm{PO}_{4}+\mathrm{KCl}, 100 \mathrm{mM}, \mathrm{pH} 7.6\right)$ with a ratio of buffer to tissue of $3.5: 1(\mathrm{v} / \mathrm{w})$. Leupeptin $(0.001 \mathrm{mM})$, PMSF $(0.2 \mathrm{mM})$, sodium EDTA $(0.2 \% \mathrm{w} / \mathrm{v})$ and $\mathrm{NaN}_{3}$ $(0.02 \% \mathrm{w} / \mathrm{v})$ were added at the time of homogenization. The homogenate was stirred at $4{ }^{\circ} \mathrm{C}$ for $2 \mathrm{~h}$, then it was centrifuged at $27000 \times g$ for $1 \mathrm{~h}$. The pellet obtained after the first centrifugation was homogenized in $4 \mathrm{~L}$ of the same buffer $(10 \mathrm{mM}$ potassium phosphate), gently stirred overnight, and centrifuged at $27000 \times g$ for $1 \mathrm{~h}$. The second supernatant, as the first, was retained and the pellet was discarded.

\subsubsection{Acid precipitation}

Supernatants from the first and second extractions were collected together. The supernatant solution (35 $924 \mathrm{mg}$ of protein) was adjusted to $\mathrm{pH} 4.5$ with $1 \mathrm{M} \mathrm{H}_{3} \mathrm{PO}_{4}$, stirred for $5 \mathrm{~min}$ and then allowed to precipitate at $4{ }^{\circ} \mathrm{C}$ for $2 \mathrm{~h}$. Afterwards, the sample was centrifuged at $27000 \times g$ for $1 \mathrm{~h}$, and the pellet was discarded. Its $\mathrm{pH}$ was readjusted to 7.6 with $1 \mathrm{M} \mathrm{KOH}$.

\subsubsection{Ammonium sulfate precipitations}

The proteins $(20236 \mathrm{mg}$ ) were precipitated by ammonium sulfate (AS) at $40 \%$ saturation for $16 \mathrm{~h}$. After centrifugation $(27000 \times g$ for $1 \mathrm{~h})$, ammonium sulfate was added to the supernatant to achieve $80 \%$ saturation. After overnight precipitation, the solution was centrifuged at $27000 \times g$ for $1 \mathrm{~h} 30 \mathrm{~min}$. The pellet ( $3855 \mathrm{mg}$ of protein) 
was resuspended in $500 \mathrm{~mL}$ of Tris- $\mathrm{HCl}$ buffer (10 mM, pH 7.6), extensively dialyzed against the same buffer (48 h) and centrifuged $(36000 \times g$ for $30 \mathrm{~min})$ to eliminate insoluble proteins.

\subsubsection{Anion-exchange chromatography}

The fraction isolated by $40-80 \%$-saturated ammonium sulfate was loaded on a $14 \times 18$-cm DEAE-Sephadex A25 (Amersham Pharmacia Biotech, Uppsala, Sweden) column which had previously been equilibrated with $10 \mathrm{mM}$ Tris- $\mathrm{HCl}$ buffer (pH 7.6). Five steps of increasing ionicstrength buffer $(0.02,0.04,0.08,0.16$ and $0.32 \mathrm{M} \mathrm{NaCl}$ ) were used for the elution of the column. All the fractions from the DEAE-Sephadex chromatography were concentrated (Amicon Ultrafiltraton System; Danvers, MA) to a final volume of $200 \mathrm{~mL}$, were extensively dialyzed against $5 \mathrm{mM}$ ammonium bicarbonate $(\mathrm{pH} 8)$ and were lyophilized.

\subsubsection{Cation-exchange FPLC}

Approximately $200 \mathrm{mg}$ from each DEAE step was chromatographed separately on a $1 \times 3-\mathrm{cm}$ CM Ceramic HyperD F column (BioSepra, Cergy-Saint Christophe, France) previously equilibrated in $10 \mathrm{mM}$ ammonium acetate ( $\mathrm{pH}$ 5.2). After elution of the unbound proteins, a linear salt gradient $(0-0.5 \mathrm{M} \mathrm{NaCl})$ was applied at a flow rate of $1.5 \mathrm{~mL} \cdot \mathrm{min}^{-1}$. Fractions of $3 \mathrm{~mL}$ were collected and monitored by UV absorption at $280 \mathrm{~nm}$. Fractions of each peak were pooled, extensively dialyzed (36-48 h) against $5 \mathrm{mM}$ ammonium bicarbonate $(\mathrm{pH} 8)$, centrifuged at $36000 \times g$ for $30 \mathrm{~min}$ and lyophilized.

\subsection{Protocol 2}

\subsubsection{Protein extraction}

Fetal cotyledons from early (553 g) and middle $(890 \mathrm{~g})$ gestational ages were thawed, finely minced, and homogenized with a hand mixer in $50 \mathrm{mM}$ ammonium bicarbonate buffer ( $\mathrm{pH} 8.5$ ) or a $300 \mathrm{mM}$ $\mathrm{KCl}$ solution ( $\mathrm{pH}$ 5), respectively. The ratio of buffer to tissue was 3.5:1 (v/w). Leupeptin $(0.001 \mathrm{mM})$, PMSF $(0.2 \mathrm{mM})$, sodium EDTA $(0.2 \% \mathrm{w} / \mathrm{v})$ and $\mathrm{NaN}_{3}$ $(0.02 \% \mathrm{w} / \mathrm{v})$ were added at the time of homogenization. The homogenates were stirred at $4{ }^{\circ} \mathrm{C}$ for $4 \mathrm{~h}$, then they were centrifuged at $27000 \times g$ for $1 \mathrm{~h}$ and the pellets were discarded. The supernatant solutions containing soluble proteins ( 2405 and $12096 \mathrm{mg}$, respectively) were exchanged into $5 \mathrm{mM}$ sodium acetate buffer ( $\mathrm{pH}$ 5.2) by means of Sephadex G-25 filtration (Pharmacia) and concentrated by ultrafiltration to 60 and $1000 \mathrm{~mL}$, respectively.

\subsubsection{Affinity column chromatography}

Approximately 800 and $500 \mathrm{mg}$ (20 and $40 \mathrm{~mL}$ ) of crude extract placental proteins from early and middle gestational ages were loaded separately on a $1 \times 4-\mathrm{cm}$ pepstatinagarose column (Sigma Chemical Co., St. Louis, MO) previously equilibrated with $50 \mathrm{mM}$ sodium acetate ( $\mathrm{pH}$ 5.2). After loading, the column was washed with the equilibration buffer until the optical density (OD) at $280 \mathrm{~nm}$ decreased to below 0.05 . After the application of a linear salt gradient ( 0 to $1 \mathrm{M} \mathrm{NaCl})$ to elute the weakly bound proteins, a linear $\mathrm{pH}$ gradient (5.2-10) was applied at a flow rate of $0.5 \mathrm{~mL} \cdot \mathrm{min}^{-1}$. Fractions of $1.0 \mathrm{~mL}$ were collected and monitored by spectrophotometry at $280 \mathrm{~nm}$. Fractions from the same peak were pooled, extensively dialyzed (36-48 h) against $5 \mathrm{mM}$ ammonium bicarbonate $(\mathrm{pH} 8)$, centrifuged at $36000 \times g$ for $30 \mathrm{~min}$ and lyophilized.

\subsection{Gel electrophoresis}

One-dimensional SDS-PAGE was carried out with and without mercaptoethanol $(5 \%)$ on a vertical cell system. Slab gels (12\% acrylamide) were run at $20 \mathrm{~mA}$ during the migration in the stacking gel and at 
$40 \mathrm{~mA}(6 \mathrm{~h})$ in the separating gel $(20 \times 10 \times$ $0.2 \mathrm{~cm}$ ). Molecular weight standards (LMW Electrophoresis Calibration Kit; Pharmacia) were run simultaneously. Proteins were either visualized after Coomassie Brilliant Blue R250 (Merck, Darmstad, Germany) staining or transferred onto a nitrocellulose membrane (Hybond ECL, Pharmacia) for Western blotting.

Two-dimensional gel electrophoresis were performed by using pH 3-10 Immobiline Drystrips $(11 \mathrm{~cm}$, Pharmacia) for the first dimension, followed by SDS-PAGE $(12 \%)$ in the second dimension. After an overnight hydration in an Immobiline DryStrip Reswelling Tray (Pharmacia), focusing was carried out at $300 \mathrm{~V}$ for $30 \mathrm{~min}, 1000 \mathrm{~V}$ for $30 \mathrm{~min}, 1550 \mathrm{~V}$ for $16 \mathrm{~h}$ and then at $1850 \mathrm{~V}$ for $1 \mathrm{~h}$ in a Flat Bed Apparatus (FBE-3 000, Pharmacia). Proteins were transferred to $0.2 \mu \mathrm{m}$ polyvinylidene difluoride (PVDF) membranes (Bio-Rad, Richmond, CA) on a 2117 Multiphor II Apparatus (Pharmacia). Transfer was carried out at constant voltages (12 V for $45 \mathrm{~min}$ and $36 \mathrm{~V}$ for $45 \mathrm{~min}$ ) for sequencing.

\subsection{Immunoblotting of transferred proteins}

Proteins in the slab gel were transferred onto nitrocellulose membrane immediately after one-dimensional SDS-PAGE, essentially as described by Towbin et al. [21]. Transfer was carried out at a constant current of $24 \mathrm{~mA}$ for $1 \mathrm{~h}$ and then at $36 \mathrm{~mA}$ overnight (Multiphor II Apparatus; Pharmacia). After protein visualization with Ponceau S (Merck), nitrocellulose membranes were washed with Tris buffered saline (TBS, $\mathrm{pH}$ 7.6) containing $3 \%$ BSA $(3 \times 10 \mathrm{~min}$ at $37^{\circ} \mathrm{C}$ ), and then incubated separately ( $3 \mathrm{~h}$ at $37{ }^{\circ} \mathrm{C}$ ) with three different rabbit antisera raised against bovine (boPAG-1; R497) or caprine PAGs (anti-caPAG ${ }_{55+62}$ and $\mathrm{caPAG}_{55+59}$; R706 and R708, respectively). Antisera were used at a dilution of 1:200 in a mixture of PAG-serum free and TBS containing 1\% BSA (24:75 v/v). After incubation, the membranes were washed with TBS containing $1 \% \mathrm{BSA}(3 \times 10 \mathrm{~min}$ at $\left.37^{\circ} \mathrm{C}\right)$ and were incubated $\left(2 \mathrm{~h}\right.$ at $\left.37^{\circ} \mathrm{C}\right)$ with sheep anti-rabbit IgG horseradish peroxidase (HPR-POD; Chemicon International Incorporation, Temecula, CA) diluted to 1:2000 in TBS containing 1\% BSA. After the second incubation, nitrocellulose paper was washed with TBS $\left(4 \times 10 \mathrm{~min}\right.$ at $\left.20^{\circ} \mathrm{C}\right)$ and the peroxidase substrate $(100 \mathrm{~mL}$ TBS, $100 \mu \mathrm{L} \mathrm{H}_{2} \mathrm{O}_{2}, 20 \mathrm{~mL}$ methanol and $60 \mathrm{mg}$ chloronaphthol; $15 \mathrm{~min}$ at $0{ }^{\circ} \mathrm{C}$ ) was added to visualize the antigen-antibody complexes.

\section{7. $\mathrm{NH}_{2}$-terminal microsequence analysis}

The $\mathrm{NH}_{2}$-terminal amino acid (aa) sequences of the blotted proteins were determined by the Edman degradation method on a pulse liquid-phase protein sequencer (Procise 492 Applied Biosystems, Foster City, CA). The sequences obtained were compared to known protein sequences in the Swiss-Prot, Trembl and TremblNew data banks by the Fasta 3 search program [17]. The amino acid sequences reported in this work were deposited in the Swiss-Prot Database (Accession numbers P83126, P83127 and P83128).

\section{RESULTS}

\subsection{Isolation and characterization of PAG molecules extracted from zebu placentas collected late in pregnancy}

As determined by RIA, PAG-like proteins represented approximately $0.93 \%$ of the total soluble proteins extracted from 30-31-week zebu placentas. Immunoreactive proteins $(334.5 \mathrm{mg}$ ) were extracted from fetal cotyledons by homogenization treatment and remained in the supernatant after $\mathrm{pH}$ acidification (294.0 mg). After ammonium sulfate precipitation at $0-40 \%$ and 
$40-80 \%$ saturation, immunoreactive proteins represented $0.44 \%(0.76 \mathrm{mg})$ and $7.91 \%(304.91 \mathrm{mg})$ of the total soluble proteins, respectively. As shown in Table I, the 40-80\% ammonium sulfate fraction bound quantitatively to the DEAE column at $\mathrm{pH}$ 7.6. Immunoreactive proteins were mainly eluted at $\mathrm{NaCl}$ concentrations of $0.04,0.08$ and $0.16 \mathrm{M}(17.64 \%, 45.96 \%$ and $20.56 \%$ of total DEAE PAG-like activity, respectively). Despite the relatively low PAG:TP ratio of the other DEAE steps, all the fractions were treated by cation exchange chromatography.

Fast protein liquid chromatography (FPLC) profiles on the CM ceramic column were shown in Figure 2. One single immunoreactive area was observed for all DEAE loaded fractions (Fig. 2). A major peak of PAG (eluted at $\mathrm{NaCl}$ concentrations of 0.14 to $0.18 \mathrm{M}$ ) was observed for both 0.04 and $0.08 \mathrm{M} \mathrm{NaCl}$ DEAE fractions. Minor reactive areas (eluted at $\mathrm{NaCl}$ concentrations of 0.21 to $0.41 \mathrm{M}$ ) were observed for the other steps of DEAE. The molecular masses and isoeletric points of the highly immunoreactive proteins from CM ceramic chromatographies are described in Table II.

CM ceramic highly immunoreactive areas from all DEAE fractions gave several stained bands after SDS-PAGE (Fig. 3A). The major band of each area was immunoreactive by Western blot analysis with the use of anti-boPAG-1 antiserum (R497; Fig. 3B). A similar reactivity was observed when using anti-caPAG ${ }_{55+62}$ (R706) and anti$\mathrm{caPAG}_{55+59}(\mathrm{R} 708)$ antisera (data not shown). Reduction with $\beta$-mercaptoethanol had no effect on the apparent molecular masses of the major-stained bands (data not shown).

\subsection{N-terminal amino acid sequence analysis of immunoreactive proteins extracted from zebu placentas collected late in pregnancy}

The major-stained SDS-PAGE proteins corresponding to the immunoreactive Western blot bands had their amino-terminal sequences determined. After CM ceramic chromatography of 0.04 and $0.08 \mathrm{M} \mathrm{NaCl} \mathrm{DEAE}$ fractions, the immunoreactive bands revealed the RGSXLTTHPLRNIKDLVYMG amino acid sequence, corresponding to the amino terminus of boPAG-1 (Swiss-Prot database accession number Q29432). N-terminal microsequencing (10 aa) of immunoreacive bands from $0,0.02$ and $0.16 \mathrm{M} \mathrm{NaCl}$ DEAE fractions also revealed $100 \%$ sequence identity with boPAG-1.

Two-dimensional gel electrophoresis analysis showed that each immunoreactive band was composed of several proteins with different isoeletric points (Tab. II).

Table I. Quantity of immunoreactive PAG and total protein (TP) of the fractions eluted from the DEAE-Sephadex A25.

\begin{tabular}{lrcc}
\hline $\begin{array}{l}\text { DEAE fraction } \\
(\mathrm{NaCl} \text { concentration })\end{array}$ & $\begin{array}{c}\mathrm{PAG}^{\mathrm{a}} \\
(\mathrm{mg})\end{array}$ & $\begin{array}{c}\mathrm{TP}^{\mathrm{b}} \\
(\mathrm{mg})\end{array}$ & $\begin{array}{c}\text { PAG:TP ratio } \\
(\times 100)\end{array}$ \\
\hline $0 \mathrm{M}$ & 8.33 & 282.7 & 2.95 \\
$0.02 \mathrm{M}$ & 5.63 & 114.6 & 4.91 \\
$0.04 \mathrm{M}$ & 30.74 & 176.3 & 17.44 \\
$0.08 \mathrm{M}$ & 80.07 & 292.9 & 27.34 \\
$0.16 \mathrm{M}$ & 35.78 & 666.0 & 5.37 \\
$0.32 \mathrm{M}$ & 7.49 & 292.4 & 2.56 \\
\hline
\end{tabular}

${ }^{\text {a }}$ Determined by boPAG-1 RIA.

${ }^{b}$ Determined by the Lowry method as the BSA equivalent. 

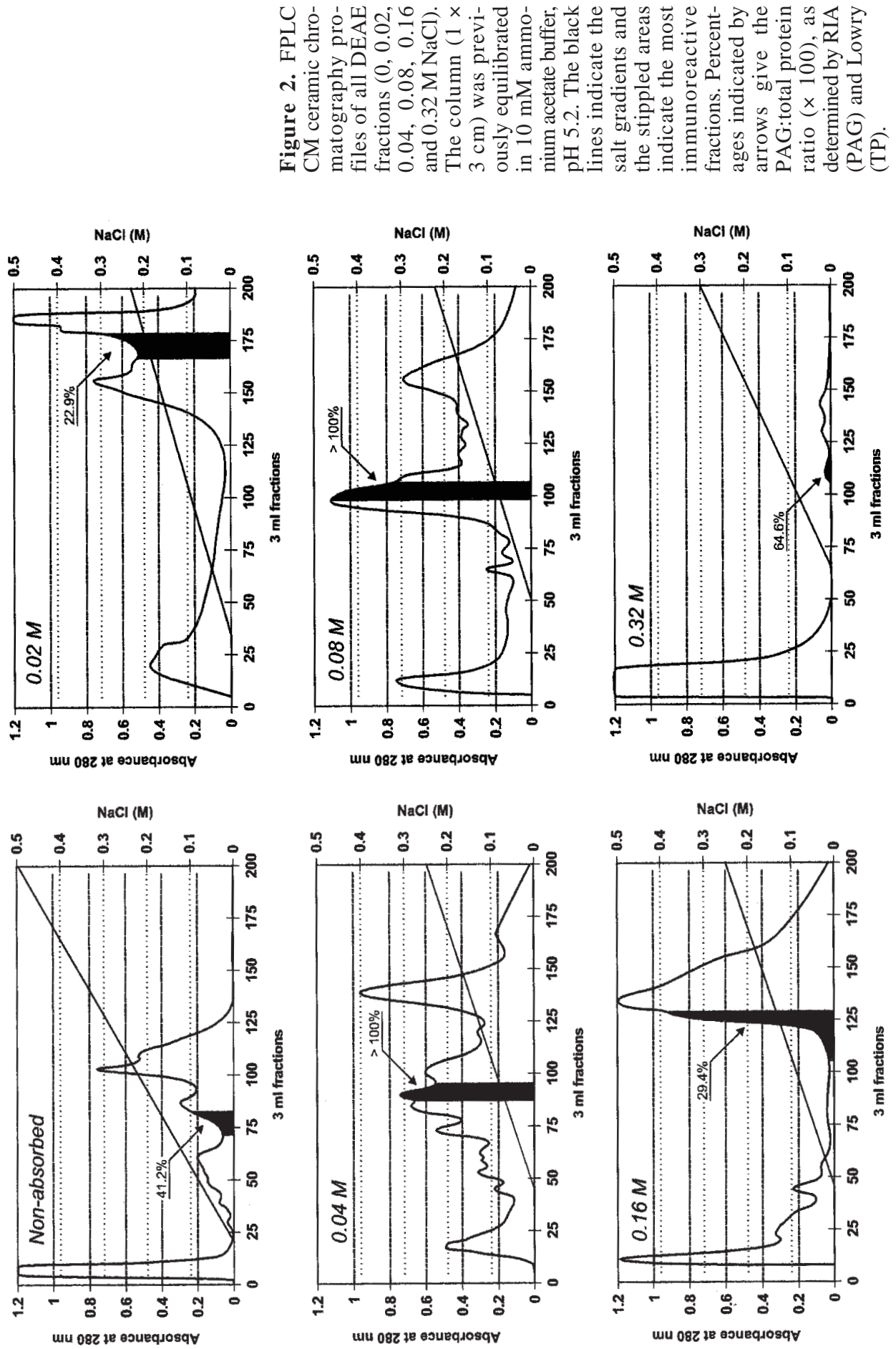
Table II. Electrophoretic characteristics and N-terminal microsequence identities of the highly immunoreactive proteins isolated after CM ceramic chromatography of the DEAE fractions.

\begin{tabular}{|c|c|c|c|c|}
\hline \multirow[t]{2}{*}{$\begin{array}{l}\text { DEAE } \\
\text { fraction origin }\end{array}$} & \multicolumn{2}{|c|}{$\begin{array}{c}\text { MM of major stained } \\
\text { bands* }\end{array}$} & \multirow[t]{2}{*}{$\begin{array}{l}\text { pIs of major } \\
\text { reactive proteins }\end{array}$} & \multirow[t]{2}{*}{$\begin{array}{c}\text { Identity at the } \\
\text { N-terminal aa sequence }\end{array}$} \\
\hline & Coomassie blue & Western blot & & \\
\hline $0 \mathrm{M}$ & $51 \mathrm{kDa}$ & $50 \mathrm{kDa}$ & $6.4,6.6,6.7$ & boPAG-1 (10 aa) \\
\hline $0.02 \mathrm{M}$ & $62 \mathrm{kDa}$ & $56 \mathrm{kDa}$ & $5.2,5.5$ & boPAG-1 (10 aa) \\
\hline $0.04 \mathrm{M}$ & $66 \mathrm{kDa}$ & $67 \mathrm{kDa}$ & $5.1,5.2,5.4$ & boPAG-1 (25 aa) \\
\hline $0.08 \mathrm{M}$ & $67 \mathrm{kDa}$ & $71 \mathrm{kDa}$ & $5.0,5.1,5.2,5.3$ & boPAG-1 (25 aa) \\
\hline $0.16 \mathrm{M}$ & $67 \mathrm{kDa}$ & $67 \mathrm{kDa}$ & $4.4,5.0,5.5,6.0$ & boPAG-1 (10 aa) \\
\hline & $60 \mathrm{kDa}$ & - & - & - \\
\hline $0.32 \mathrm{M}$ & $62 \mathrm{kDa}$ & $62 \mathrm{kDa}$ & $5.8,6.1,6.3,6.4$ & $\begin{array}{c}\alpha-\mathrm{N} \text {-acetyl } \\
\text { galactosaminidase (12 aa) }\end{array}$ \\
\hline
\end{tabular}

* Molecular masses (MM) were estimated after one-dimensional SDS-PAGE.

** Isoeletric points (pIs) were estimated after two-dimensional SDS-PAGE.

(A)

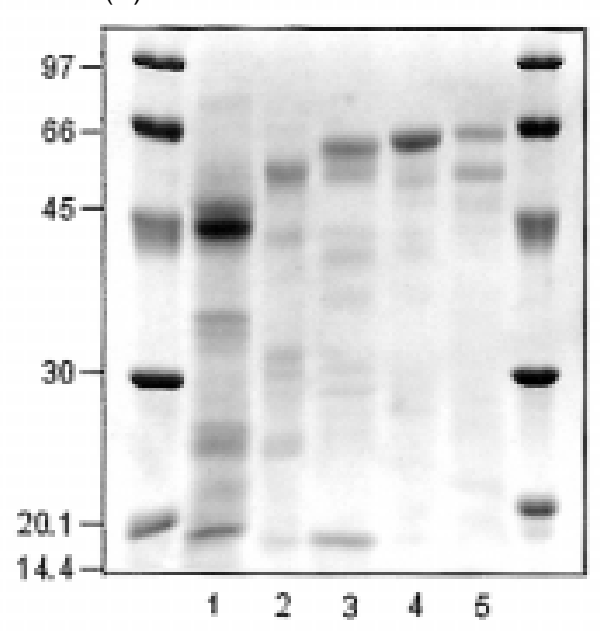

(B)

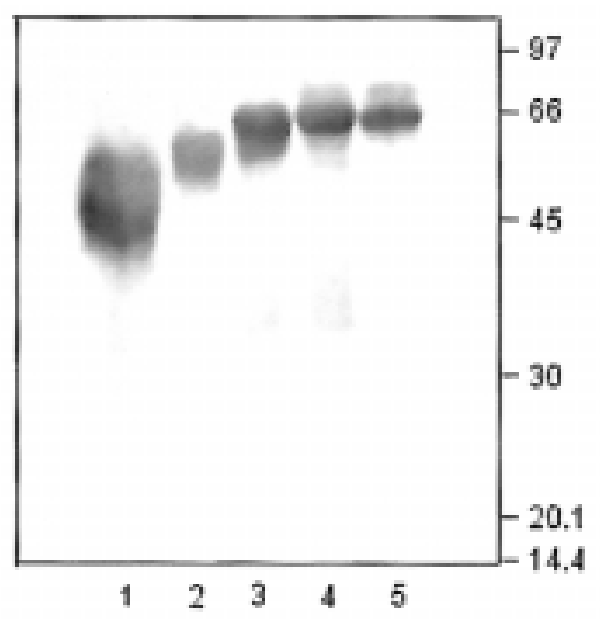

Figure 3. (A) Coomassie Blue-stained SDS-PAGE (12\%); (B) Western blot analysis with antiserum anti-boPAG-1 (R497). Lanes 1, 2, 3, 4 and 5 correspond to the most immunoreactive areas from $\mathrm{CM}$ ceramic chromatography of $0,0.02,0.04,0.08$ and $0.16 \mathrm{M} \mathrm{NaCl}$ DEAE fractions. Twenty micrograms of each CM ceramic area were loaded on each lane. Molecular weights $\left(\times 10^{-3}\right)$ are indicated on the left and right sides of the figure.

Microsequencing of the N-terminus (25 aa) of the four major spots corresponding to the immunoreactive $67 \mathrm{kDa}$ band from the $0.08 \mathrm{M} \mathrm{NaCl}$ fraction (data not shown) confirmed the presence of a single amino acid sequence.
Despite a relatively high PAG:TP ratio $(65.55 \%)$ observed for the most immunoreactive peak obtained after CM ceramic chromatography of the $0.32 \mathrm{M} \mathrm{DEAE}$ fraction, $\mathrm{N}$-terminal microsequence of the $62 \mathrm{kDa}$ protein (Fig. 4) revealed the LENGLLRKPPMG 


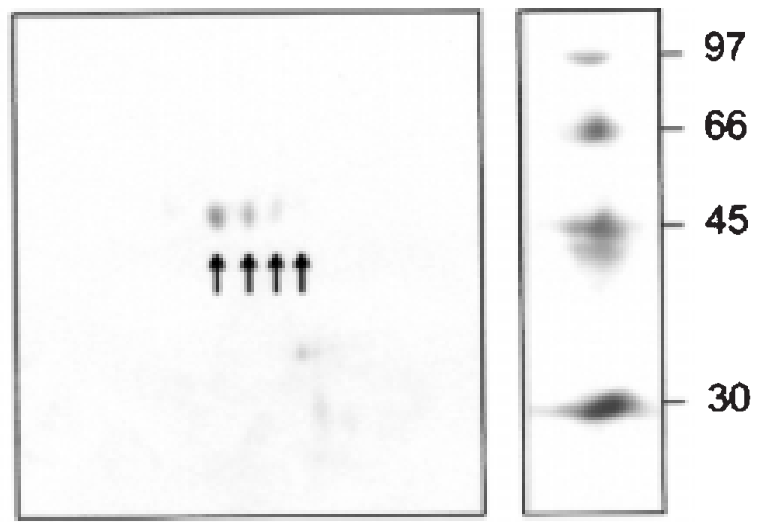

Figure 4. Two-dimensional electrophoresis of the most immunoreactive peak from $\mathrm{CM}$ ceramic chromatography of the $0.32 \mathrm{M} \mathrm{NaCl}$ DEAE fraction. Molecular weights $\left(\times 10^{-3}\right)$ are indicated in the right side. The $\mathrm{pH}$ scale is indicated at the top of the gel. Arrows indicate the different charged isoforms (6.4, $6.3,6.1$ and 5.8) of alpha-Nacetylgalactosaminidase.

sequence, which has high sequence identity $(91.7 \%)$ with murine alpha-N-acetylgalactosaminidase (Swiss-Prot database accession number O88620).

\subsection{Characterization of PAG molecules isolated by means of pepstatin-agarose affinity chromatography}

As estimated by RIA, PAG-like proteins represented approximately $0.61 \%(73.73 \mathrm{mg})$ and $1.81 \%(43.57 \mathrm{mg})$ of total proteins extracted from 20-21-week and 10-11-week gestational age zebu placentas, respectively.

The most immunoreactive peak $(15.74 \%$ PAG:TP ratio) from pepstatin-agarose affinity chromatography of 20-21-week gestational age zebu placentas extracted at $\mathrm{pH} 5$ was eluted at $\mathrm{NaCl}$ concentrations of 0.14 to $0.43 \mathrm{M}$ (Fig. 5). No proteins were eluted after linear $\mathrm{pH}$ gradient (5.2-10) application. One ,weak stained band was observed after SDS-PAGE (Fig. 6A, lane 1). Twodimensional electrophoresis of the PAGreactive peak revealed 3 major spots, the first one with an apparent molecular mass of $67 \mathrm{kDa}$, and the others with $84 \mathrm{kDa}$ molecular mass (data not shown). Microsequencing of the N-terminus of the $67 \mathrm{kDa}$ spot (14 aa) revealed $100 \%$ identity to boPAG-1. The $84 \mathrm{kDa}$ spots (pI 4.4 and 5.0) had the
$\mathrm{NH}_{2}$-terminal sequencing blocked at the first and 6 th cycles, respectively. The short $\mathrm{N}$-terminal sequence obtained (AVDGGH) did not correspond to a member of the PAGfamily.

Crude extracts from 10-11-week old zebu placenta gave several peaks after chromatography on a pepstatin-agarose column (Fig. 5). The most immunoreactive peak showed a low PAG:TP ratio (3.26\%), being eluted at $\mathrm{NaCl}$ concentrations of 0.19 to $0.42 \mathrm{M}$. After $\mathrm{pH}$ gradient application (5.2-10), no proteins were eluted. SDSPAGE analysis revealed the presence of a single major stained protein with apparent molecular mass of $69 \mathrm{kDa}$ and several weak stained bands ranging from 20 to $84 \mathrm{kDa}$ (Fig. 6A, lane 2). After Western blotting, major immunoreactive bands were observed at $69 \mathrm{kDa}$ and $84 \mathrm{kDa}$ (Fig. 6B, lanes 2). Analyzed by two-dimensional electrophoresis, the $69 \mathrm{kDa}$ protein gave 3 isoeletric variants with pIs of 3.1, 3.3 and 6.18 microsequencing of the $14 \mathrm{~N}$-terminal aa of this protein showed $100 \%$ identity with the boPAG-1. Despite the high immunoreactivity observed with the use of bovine R497 and caprine R706 and R708 antisera, the $84 \mathrm{kDa}$ protein revealed the DKNAYGIDLIL sequence, which shows $77.78 \%$ identity with the alkaline metalloproteinase (GenBank database accession 

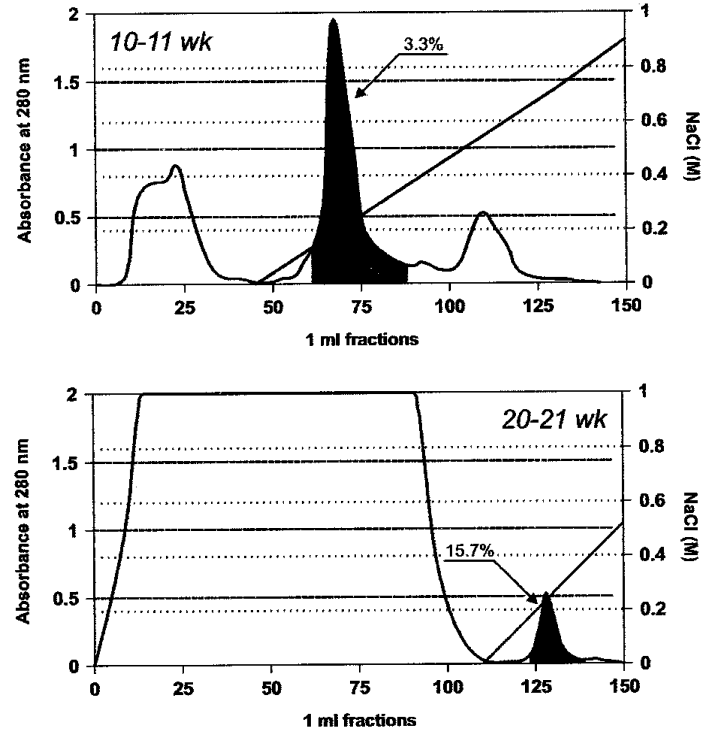

Figure 5. Pepstatin-agarose chromatographic elution profiles of proteins extracted from placentas removed at 10-11 weeks and 20-21 weeks of gestation. The column $(1 \times 3 \mathrm{~cm})$ was previously equilibrated with $50 \mathrm{mM}$ sodium acetate ( $\mathrm{pH}$ 5.2). The black lines indicate the salt gradients and the stippled areas indicate the most immunoreactive fractions. Percentages indicated by arrows give the PAG:total protein ratio $(\times 100)$, as determined by RIA (PAG) and Lowry (TP).
(A)

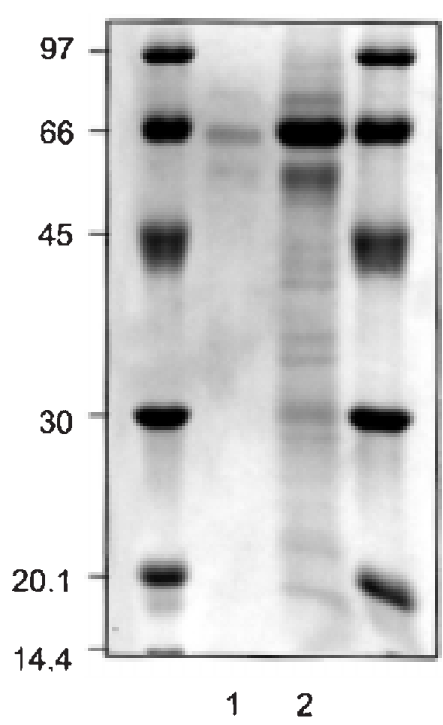

(B)

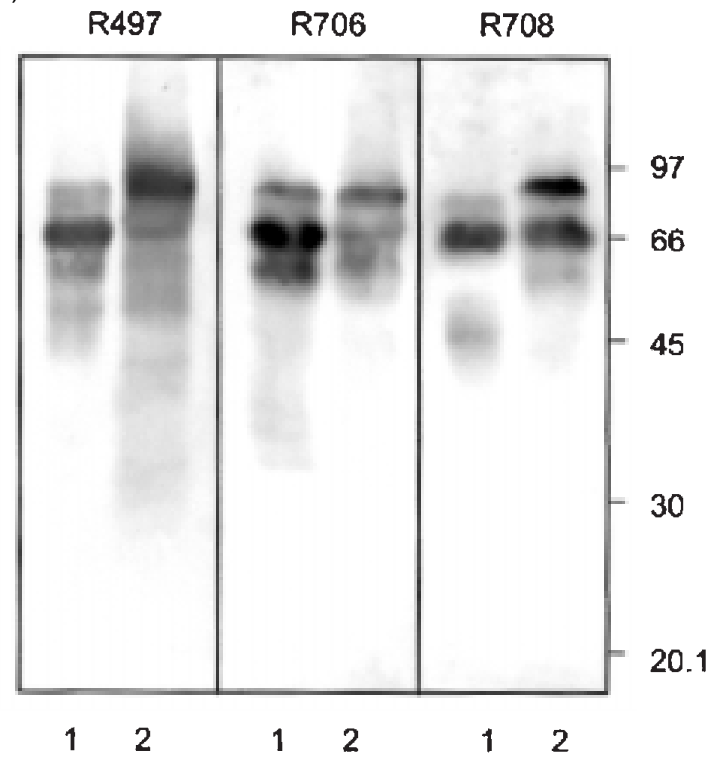

Figure 6. (A) Coomassie Blue-stained SDS-PAGE (12\%); (B) Western blot analysis with antiserum anti-boPAG-1 (R497), anti-caPAG ${ }_{55+62}$ (R706) and caPAG ${ }_{55+59}$ (R708). Lanes 1 and 2 correspond to the most immunoreactive peaks from pepstatin-agarose affinity chromatography of proteins extracted from placentas removed at 20-21 weeks and 10-11 weeks of gestation. Sixty micrograms of each immunoreactive peak were loaded on each lane. Molecular weights $\left(\times 10^{-3}\right)$ are indicated on the left and right sides of the figure. 
number AAK22731) identified in the Caulobacter crescentus genome.

\section{DISCUSSION}

In the last two decades, the biochemical isolation of pregnancy-associated or specific proteins constituted a fundamental step for the development of specific RIA systems because it allowed the isolation of relatively large amounts of purified or semipurified proteins. By means of multiple step purification procedures, several PAG molecules differing in molecular masses and charges were isolated from the placentas of cows [2, 3, 28], ewes [24, 26], goats [6], moose and elk [11], some of them being characterized at their N-terminal amino acid sequence. However, to our knowledge, no publication has been made on placental proteins extracted from zebu placentas.

In the first part of this study, a protocol including the extraction of soluble proteins, acid and ammonium sulfate precipitations and ion exchange chromatography was used to purify PAG molecules extracted from zebu placentas collected during the third trimester of pregnancy. Considered by some authors as unnecessary [11], acid precipitation constituted a critical step for PAG purification in zebu cattle. It allowed the elimination of more than $40 \%$ (approximately $16 \mathrm{~g}$ ) of total crude extract soluble proteins with an optimal recovery of immunoreactive proteins (approximately $294 \mathrm{mg}$, corresponding to $88 \%$ of the initial PAG immunoreactivity). Whether the $\mathrm{pH}$ treatment is responsible for the elimination of some PAG isoforms extracted from ruminant placenta is not known. Nevertheless, the utilization of a similar purification protocol including acid precipitation in the caprine species has allowed the isolation of three distinct PAGs with different molecular masses, each containing several isoforms [6].

As recently described, ion exchange chromatography has been proved to be very effective for the separation of different PAG molecules extracted from goat and sheep placental tissues. In the caprine species for example, after DEAE chromatography, immunoreactive proteins were equally apportioned between the $0.04 \mathrm{M}$ and $0.08 \mathrm{M} \mathrm{NaCl}$ fractions. Further fractionation of these steps revealed the presence of a common $55 \mathrm{kDa}$ protein, as well as the presence of distinct PAG molecules with masses of $59 \mathrm{kDa}$ and $62 \mathrm{kDa}$, eluting respectively at 0.04 and $0.08 \mathrm{M} \mathrm{NaCl}$ [6]. In the ovine species, the association of anion and cation exchange chromatographies allowed the characterization of four PAG molecules: ovPAG 55, ovPAG $_{60}$, ovPAG $_{61}$ and ovPAG 65 [26]. Each of these proteins had a distinct $\mathrm{NH}_{2}$-terminal amino acid sequence and a high amino acid identity with other members of the aspartic proteinase family. In the light of these findings, in the first protocol, all DEAE fractions were systematically purified by CM ceramic chromatography and analyzed by SDS-PAGE and Western blotting with the use of antisera raised against three different PAG preparations.

If we consider the different molecular masses (51 to $67 \mathrm{kDa}$ ) and isoeletric points (4.4 to 6.7), our results confirm a high heterogeneity of the PAG molecules in ruminant placentas. Specifically considering the microsequencing, our protocol did not reveal the presence of distinct PAG N-terminal amino acid sequences in the placenta extracts, despite the analysis of all immunoreactive proteins eluted at different ionic conditions. In fact, till now, all PAG, PSPB and PSP-60 related proteins purified from Bos taurus fetal cotyledons have shared the same cDNA and N-terminal amino acid sequences [3, 13, 25]. These results contrast with recent findings obtained by the screening of bovine placental libraries with different cDNA probes, which suggests the expression of at least 21 bovine PAG cDNAs coding for different amino acid sequences even at the $\mathrm{N}$-terminal part of the molecules $[8,27]$. There seems to be at 
least three possible explanations for this apparent discrepancy between the results obtained by biochemical and molecular biology techniques. The first is that, although some of the recently characterized PAG cDNAs $[8,27]$ could be transcribed and translated into PAG molecules, these proteins could be rapidly degraded and thus could not accumulate at detectable levels. The second is that, in bovine species, some of the PAG molecules could be N-terminally blocked. In this case, only co-purified non-blocked immunoreactive proteins could be identified after Edman degradation. The third explanation is that some PAGs could be linked to membranes via fatty acid linkages, being consequently more difficult to extract by conventional procedures. The latter explanation seems more unlikely because bovine PAG cDNAs code for a relatively well-conserved pepsinogen-like structure [9], which is not originally linked to membranes.

According to Xie et al. [25], the presence of N-linked carbohydrate chains accounts, at least partially, for the discrepancies in molecular masses observed after SDS-PAGE. As previously suggested by Zoli et al. [28], different degrees of glycosylation are also involved in the heterogeneity of the isoeletric point estimated for boPAG-1. Concerning N-terminal amino sequencing, similarly to the previous observations made in the taurine [28], ovine [26] and caprine species [6], Edman sequencing of PAGs extracted from the zebu placenta failed to give any signal on cycle 4 , indicating the presence of an N-glycosylated asparagine.

Although a high RIA immunoreactivity was observed for one CM ceramic peak from the $0.32 \mathrm{M} \mathrm{NaCl}$ DEAE fraction $(64.55 \%$ PAG:TP ratio), N-terminal sequencing of its major protein $(62 \mathrm{kDa})$ showed more than $75 \%$ identity with the alpha- $\mathrm{N}$-acetylgalactosaminidase ( $\alpha$-GalNAc), a lysosomal exoglycosidase synthesized in the various tissues of the murine [10], chicken [4] and human species [23]. The human $\alpha$-GalNAc was also accidentally found as one of the five major bands during purification of placental sialidases [22]. In this species, $\alpha$-GalNAc seemed to be synthesized as a $65 \mathrm{kDa}$ glycosylated precursor, which is processed to a mature $48 \mathrm{kDa}$ isoform [20]. The unexpected cross-reactivity observed between the zebu $\alpha$-GalNAc and the bovine and caprine PAG antisera could be due either to the presence of common epitopes in both classes of proteins or to the non-specificity of the polyclonal antisera used in both RIA and Western blot techniques.

According to comparative molecular modeling studies, PAGs have retained the well-known bilobed structure of aspartic proteinases, and a peptide binding cleft between the two lobes capable of accommodating peptides up to 7 amino acids. Thus, it has been hypothesized that they could be purified by the use of pepstatinagarose affinity chromatography [9, 27]. Pepstatin A is an extremely powerful inhibitor of aspartic proteinases [14]. It binds reversibly to the active center of pepsin, renin and cathepsin $\mathrm{D}$, being widely used as a ligand in affinity chromatography protocols for the isolation of these enzymes $[1,5]$. In the present work, PAG molecules were successfully identified after pepstatin affinity chromatography of cotyledonary extracts from placentas collected in both the first and second trimesters of gestation and extracted in both acid and alkaline conditions. When crude extracts from 20-21-week old zebu placentas were loaded, PAG concentration was enriched by a factor of 25.8 (a $15.74 \%$ PAG:TP ratio with the column procedure vs. a $0.61 \%$ PAG:TP ratio with the crude extract). A lower efficacy was observed after affinity chromatography of 10-11-week old zebu placenta (PAG:TP ratio $3.26 \%$ vs. $1.81 \%)$. However, in this case, the lower efficacy was more likely due to the higher viscosity of crude extracts, which could make an ideal pepstatin A-PAG interaction difficult, than to the differences in the buffers chosen for the extraction. In the present work, PAG molecules were eluted 
before a high ionic strength was attempted, indicating a weaker interaction of PAG with the pepstatin A substract. This observation is consistent with theoretical binding studies of PAG molecules that suggest that the substitution of Tyr189 and Leu220 (porcine pepsinogen numbering) by Asp residues in the boPAG-1 molecule are likely to induce a weaker binding to pepstatin A [9].

After affinity chromatography, the placenta extracts removed at both gestational ages revealed the presence of a $67 \mathrm{kDa}$ immunoreactive protein, which was $100 \%$ identical to boPAG-1 (14 aa long) according to the $\mathrm{N}$-terminal sequence. As observed in Figure 6B (lanes 2), another protein with an apparent molecular mass of $84 \mathrm{kDa}$ and showing a high immunoreactivity with 3 antisera (R497, R706 and R708) was observed after extraction from 10-11-week old zebu placentas. Its microsequencing revealed $77.78 \%$ amino acid sequence identity to an alkaline metalloproteinase (GenBank database accession number AAK22731), which was previously identified in the Caulobacter crescentus genome by Nierman et al. [16]. Two possibilities can be argued to explain the presence of this metalloproteinase in our preparation: first, bacterial proliferation during the first steps of purification, second, the specific expression of this type of metalloproteinase in the zebu placenta. It was interesting that all 3 antisera recognized this protein. The characterization of the epitope(s) responsible for this cross-reaction is worthy of further investigations.

In conclusion, this investigation was the first on the pregnancy-associated glycoproteins in the Bos indicus placenta. Using SDS-PAGE and Western blotting, different isoforms of PAG with apparent molecular masses from 51 to $69 \mathrm{kDa}$ and isoeletric points varying from 4.4 to 6.7 were identified in placentas recovered at different gestational ages. $\mathrm{N}$-terminal microsequencing indicated that these proteins share a common PAG amino acid sequence (Swiss-Prot database accession number P83126), which is identical to that previously described in the Bos taurus cattle. In addition to PAG molecules, two other immunoreactive proteins (Swiss-Prot database accession numbers P83127 and P83128) showing high $\mathrm{N}$-terminal amino acid identity with alpha$\mathrm{N}$-acetylgalactosaminidase and alkaline metalloproteinase were identified for the first time in zebu placenta extracts. Complementary studies are in progress to characterize the PAG profiles during gestation and postpartum periods in zebu cattle.

\section{ACKNOWLEDGMENTS}

This work was supported by a scholarship from Brazilian Coordination of Training of Higher Educate Graduate (CAPES/Brazil) to N.M.S. and by grants from F.N.R.S. and the Belgium Ministry of Agriculture to J.F.B. The authors thank Dr. M.A.N. Dode for assistance with zebu placenta collection, Mrs. N. GérardinOtthiers (University of Liege) and Dr. R. Wattiez (University of Mons-Hainaut) for peptide sequence analyses, Dr. E. McNamara, Department of General Human Biochemistry and Pathology (ULg) for carefully reading the manuscript and Mr. C. Ernotte for editorial assistance.

\section{REFERENCES}

[1] Afting E.G., Becker M.L., Two-step affinitychromatographic purification of cathepsin D from pig myometrium with high yield, Biochem. J. 197 (1981) 519-522.

[2] Butler J.E., Hamilton W.C., Sasser R.G., Ruder C.A., Hass G.M., Williams R.J., Detection and partial characterization of two bovine pregnancyspecific proteins, Biol. Reprod. 26 (1982) 925-933

[3] Camous S., Charpigny G., Guillomot M., Martal J., Purification of one pregnancy-specific protein by high-performance liquid chromatography (HPLC), in: Proceedings of Bard Workshop, Maternal Recognition of Pregnancy and Maintenance of the Corpus Luteum, Jerusalem, 1988, Abstract 2.

[4] Davis M.O., Hata D.J., Smith D., Walker J.C., Cloning and sequence of a chicken alpha-Nacetylgalactosaminidase gene, Biochim. Biophys. Acta 1216 (1993) 296-298. 
[5] Dzau V.J., Slater E.E., Haber E., Complete purification of dog renal renin, Biochemistry 18 (1979) 5224-5228.

[6] Garbayo J.M., Remy B., Alabart J.L., Folch J., Wattiez R., Falmagne P., Beckers J.F., Isolation and partial characterization of a pregnancyassociated glycoprotein family from the goat placenta, Biol. Reprod. 58 (1998) 109-115.

[7] Garbayo J.M., Green J.A., Manikkam M. Beckers J.F., Kiesling D.O., Ealy A.D., Roberts R.M., Caprine pregnancy-associated glycoproteins (PAG): their cloning, expression, and evolutionary relationship to other PAG, Mol. Reprod. Dev. 57 (2000) 311-322.

[8] Green J.A., Xie S., Quan X., Bao B., Gan X., Mathialagan N., Beckers J.F., Roberts R.M. Pregnancy-associated bovine and ovine glycoproteins exhibit spatially and temporally distinct expression patterns during pregnancy, Biol. Reprod. 62 (2000) 1624-1631.

[9] Guruprasad K., Blundell T.L., Xie S., Green J., Szafranska B., Nagel R.J., McDowell K., Baker C.B., Roberts R.M., Comparative modelling and analysis of amino acid substitutions suggests that the family of pregnancy-associated glycoproteins includes both active and inactive aspartic proteinases, Protein Eng. 9 (1996) 849-856.

[10] Herrmann T., Schindler D., Tabe H., Onodera O., Igarashi S., Polack A., Zehnpfennig D., Tsuji S., Molecular cloning, structural organization, sequence, chromosomal assignment, and expression of the mouse alpha-N-acetylgalactosaminidase gene, Gene 211 (1998) 205-214.

[11] Huang F., Cockrell D.C., Stephenson T.R., Noyes J.H., Sasser R.G. Isolation, purification, and characterization of pregnancy-specific protein B from elk and moose placenta, Biol. Reprod. 61 (1999) 1056-1061.

[12] Lowry O.H., Rosebrough N.J., Farr A.L., Randall R.G., Protein measurement with the folin pheno reagent, J. Biol. Chem. 193 (1951) 265-275.

[13] Lynch K.A., Alexander R.M., Sasser R.G. The cloning and expression of the bovine pregnancy specific protein B (bPSPB) gene, Biol. Reprod. 46 Suppl. 1 (1992) 73 (Abstract 89).

[14] Marciniszyn J.Jr., Hartsuck J.A., Tang J., Pepstatin inhibition mechanism, Adv. Exp. Med. Biol. 95 (1977) 199-210.

[15] Mialon M.M., Camous S., Renand G., Martal J., Menissier F., Peripheral concentrations of a 60-kDa pregnancy serum protein during gestation and after calving and in relationship to embryonic mortality in cattle, Reprod. Nutr. Dev. 33 (1993) 269-282.

[16] Nierman W.C., Feldblyum T.V., Laub M.T., Paulsen I.T., Nelson K.E., Eisen J., Heidelberg J.F., Alley M.R., Ohta N., Maddock J.R., Potocka I., Nelson W.C., Newton A., Stephens C.,
Phadke N.D., Ely B., DeBoy R.T., Dodson R.J. Durkin A.S., Gwinn M.L., Haft D.H., Kolonay J.F., Smit J., Craven M.B., Khouri H., Shetty J., Berry K., Utterback T., Tran K., Wolf A., Vamathevan J., Ermolaeva M., White O., Salzberg S.L., Venter J.C., Shapiro L., Fraser C.M., Complete genome sequence of Caulobacter crescentus, Proc. Natl. Acad. Sci. USA 98 (2001) 4136-4141.

[17] Pearson W.R., Lipman D.J., Improved tools for biological sequence, Proc. Natl. Acad. Sci. USA 85 (1988) 2444-2448.

[18] Sasser R.G., Ruder C.A., Ivani K.A., Butler J.E., Hamilton W.C., Detection of pregnancy by radioimmunoassay of a novel pregnancy-specific protein in serum of cows and a profile of serum concentrations during gestation, Biol. Reprod. 35 (1986) 936-942.

[19] Sousa N.M., Figueiredo J.R., Beckers J.F., Placental proteins in ruminants: biochemical, physiological and zootechnical aspects, in: Renaville R., Burny A. (Eds.), Biotechnology in Animal Husbandry, 1st ed., Dordrecht: Kluwer Academic Publishers, 2001, pp. 179-208.

[20] Sweeley C.C., Ledonne N.C. Jr., Robbins P.W., Post-translational processing reactions involved in the biosynthesis of lysosomal alpha-N-acetylgalactosaminidase in cultured human fibroblasts, Arch. Biochem. Biophys. 223 (1983) 158-165.

[21] Towbin H., Stachelin T., Gordon J., Eletrophoretic transfer of proteins from polyacrylamide gels to nitrocellulose sheets: procedure and some applications, Proc. Natl. Acad. Sci. USA 76 (1979) 4350-4354.

[22] Tsuji S., Yamauchi T., Hiraiwa M., Isobe T., Okuyama T., Sakimura K., Takahashi Y., Nishizawa M., Uda Y., Miyatake T., Molecular cloning of a full-length cDNA for human alpha-N-acetylgalactosaminidase (alpha-galactosidase B), Biochem. Biophys. Res. Commun. 163 (1989) 1498-1504.

[23] Wang A.M., Bishop D.F., Desnick R.J., Human alpha-N-acetylgalactosaminidase-molecular cloning, nucleotide sequence, and expression of a full-length cDNA. Homology with human alpha-galactosidase A suggests evolution from a common ancestral gene, J. Biol. Chem. 265 (1990) 21859-21866.

[24] Willard J.M., White D.R., Wesson C.A., Stellflug J., Sasser R.G., Detection of fetal twins in sheep using a radioimmunoassay for pregnancy-specific protein B, J. Anim. Sci. 73 (1995) 960-966.

[25] Xie S., Low R.C., Nagel R.J., Kramer K.K. Anthony R.V., Zoli A.P., Beckers J.F., Roberts R.M., Identification of the major pregnancyspecific antigens of cattle and sheep as inactive members of the aspartic proteinase family, Proc Natl. Acad. Sci. USA 88 (1991) 10247-10251. 
[26] Xie S., Green J.A., Bao B., Beckers J.F., Valdez K.E., Hakami L., Roberts R.M., Multiple pregnancy-associated glycoproteins are secreted by day 100 ovine placental tissue, Biol. Reprod. 57 (1997) 1384-1393.

[27] Xie S., Green J.A., Bixby J.B., Szafranska B., DeMartini J.C., Hecht S., Roberts R.M., The diversity and evolutionary relationships of the pregnancy-associated glycoproteins, an aspartic proteinase subfamily consisting of many trophoblast-expressed genes, Proc. Natl. Acad. Sci. USA 94 (1997) 12809-12816.

[28] Zoli A.P., Beckers J.F., Wouters-Ballman P. Closset J., Falmagne P., Ectors F., Purification and characterization of a bovine pregnancy-associated glycoprotein, Biol. Reprod. 45 (1991) 1-10.

[29] Zoli A.P., Guilbault L.A., Delahaut P., BenitezOrtiz W., Beckers J.F., Radioimmunoassay of a bovine pregnancy-associated glycoprotein in serum: its application in pregnancy diagnosis, Biol. Reprod. 46 (1992) 83-92. 